\title{
THE ROUTLEDGE COMPANION TO LABOR AND MEDIA
}

Edited by Richard Maxwell 
First published 2016

by Routledge

711 Third Avenue, New York, NY 10017

and by Routledge

2 Park Square, Milton Park, Abingdon, Oxon OX14 4RN

Routledge is an imprint of the Taylor $\mathcal{E}$ Francis Group, an informa business

(C) 2016 Taylor \& Francis

The right of the editor to be identified as the author of the editorial material, and of the authors for their individual chapters, has been asserted in accordance with sections 77 and 78 of the Copyright, Designs and Patents Act 1988.

All rights reserved. No part of this book may be reprinted or reproduced or utilised in any form or by any electronic, mechanical, or other means, now known or hereafter invented, including photocopying and recording, or in any information storage or retrieval system, without permission in writing from the publishers.

Trademark notice: Product or corporate names may be trademarks or registered trademarks, and are used only for identification and explanation without intent to infringe.

\section{Library of Congress Cataloging-in-Publication Data}

The Routledge companion to labor and media / edited by Richard Maxwell. pages $\mathrm{cm}$

Includes bibliographical references and index.

1. Mass media-Economic aspects. 2. Mass media-Employees. I. Maxwell, Richard, 1957-

P96.E25R68 2015

$331.7^{\prime} 6130223-\mathrm{dc} 23$

2015002563

ISBN: 978-0-415-83744-6 (hbk)

ISBN: 978-0-203-40411-9 (ebk)

Typeset in Goudy

by Apex CoVantage, LLC

Printed and bound by CPI Group (UK) Ltd, Croydon, CR0 4YY 


\section{CONTENTS}

Notes on Contributors viii

Foreword xiv

JANET WASKO

Introduction

xvi

RICHARD MAXWELL

\section{SECTION I}

The Changing Face of Media Labor: Networks, Clouds, and Digitalized Work

1 Labor and Digital Capitalism

DAN SCHILLER

2 Working (or Not) in the Cloud: Chains of Accumulation and Chains of Resistance VINCENT MOSCO

3 Exploitation and Media Labor

DAVID HESMONDHALGH

4 Mediations of Labor: Algorithmic Architectures, Logistical Media, and the Rise of Black Box Politics

SOENKE ZEHLE AND NED ROSSITER

5 Dallas Smythe and Digital Labor CHRISTIAN FUCHS

\section{SECTION II}

Materials and Chemical Impact on Workers and Consumers

6 The Body Burden: Toxics, Stresses, and Biophysical Health ELIZABETH GROSSMAN

7 Health and Safety Policies for Electronics Workers TED SMITH AND CHAD RAPHAEL 
SECTION III

Media Labor Around the World

8 Workers of the World, Unite, You Have Nothing to Lose but Your (Global Value) Chains: The NICL Revisited TOBY MILLER

9 Embracing Communication: China's Post-2008 Economic Restructuring and Labor YU HONG AND WEI WANG

10 "Free Birds": The New Precariat in India's Mobile Phone Manufacturing ANIBEL FERUS-COMELO

11 Behind the Line: Information Privatization and the Reification of Work in the Call Center of a Brazilian State-Owned Telecommunications Company SIMONE WOLFF

12 The Creative in the Middle: Knowledge Workers in a Medium-Sized Company in Spain LUIS REYGADAS

13 The Exceptional Intermittents du Spectacle: Hyperflexibility as the Avant-Garde of Labor Security in France JONATHAN BUCHSBAUM

14 UK Art Workers, Class, and the Myth of Mobility MARK BANKS AND KATE OAKLEY

15 The Unfunny Tale of Labor and Cartooning in the US and Around the World JOHN A. LENT

16 The Straw That Broke the Tiger's Back? Skilled Labor, Social Networks, and Protest in the Digital Workshops of the World LEON GUREVITCH

17 Crisis or Innovation? The Norwegian Journalist Between Market and Ideals in the Multimedia Era RUNE OTTOSEN

18 History of the International Movement of Journalists: Shifting Drives of Profession, Labor, and Politics FRANK BEYERSDORF AND KAARLE NORDENSTRENG

19 The Planned Obsolescence of TV Journalism GERALD SUSSMAN AND CAREY L. HIGGINS-DOBNEY

20 Student Media Labor in the Digital Age: MediaNOLA in the Classroom and the University VICKI MAYER AND JOCELYN HORNER 


\section{CONTENTS}

21 The Work of Wearing Cameras: Body-Worn Devices and Police Media Labor KELLYGATES

\section{SECTION IV}

Activism, Organization, Worker Resistance, and

Media Labor's Future

22 The GoodElectronics Network: Making IT Fair?

PAULINE OVEREEM, GOODELECTRONICS NETWORK COORDINATOR WITH VICKY ANNING

23 Centro de Reflexión y Acción Laboral: Defending Electronics

Workers in Mexico

PEDRO ANTONIO REYES LINARES FOR CEREAL

(CENTRO DE REFLEXIÓN Y ACCIÓN LABORAL

EN GUADALAJARA)

24 Chinese Labor Protest and Trade Unions

JENNY CHAN, NGAI PUN, AND MARK SELDEN

25 Locating Worker-Generated Content (WGC) in the World's Factory JACK LINCHUAN QIU

26 Labor Messaging: Practices of Autonomous Communication ENDA BROPHY, NICOLE S. COHEN, AND GREIG DE PEUTER

27 The Future of Activism for Electronics Workers

CHAD RAPHAEL AND TED SMITH

Bibliography

Index 


\section{NOTES ON CONTRIBUTORS}

Mark Banks is Professor of Culture and Communication in the Department of Media and Communication at the University of Leicester. Recent publications include the report Working Lives in Black British Jazz (with Jason Toynbee and Jill Ebrey) and the edited collection Theorizing Cultural Work: Labour, Continuity and Change in the Cultural and Creative Industries (with Ros Gill and Stephanie Taylor).

Frank Beyersdorf teaches European and German history at Free University and Humboldt University of Berlin. His current research analyzes attempts of international media actors to create global information orders between 1919 and the early 1950s. He has published on the League of Nations, international telecommunication policy, the Cold War, and internet governance.

Enda Brophy is Assistant Professor in the School of Communication, Simon Fraser University. He is completing a manuscript on labor resistance in global call centers (tentatively titled Language Put to Work: Labour and Communicative Capitalism), and is collaborating with Greig de Peuter and Nicole Cohen on Cultural Workers Organize, a research project into collective responses to precarity by workers in the creative industries.

Jonathan Buchsbaum is Professor of Media Studies at Queens College, City University of New York. He is the author of Cinema Engagé: Film in the Popular Front, Cinema and the Sandinistas: Filmmaking in Revolutionary Nicaragua, 1979-1990, and the forthcoming Exception Taken: How France Has Defied Hollywood's New World Order.

Jenny Chan is Lecturer in Contemporary China Studies, School of Interdisciplinary Area Studies, University of Oxford. Educated at the Chinese University of Hong Kong (BSSc in Sociology) and the University of Hong Kong (MPhil in Sociology), she was a Reid Research Scholar while pursuing her $\mathrm{PhD}$ at the University of London. In 2013-2014, she received the prestigious Great Britain-China Educational Award. Currently, she serves as Board Member of the International Sociological Association's Research Committee on Labor Movements (2014-2018). Her recent articles have appeared in Current Sociology, Modern China, Human Relations, Critical Asian Studies, Global Labor Journal, The Asia-Pacific Journal, The South Atlantic Quarterly, New Labor Forum, and New Technology, Work and Employment.

Nicole S. Cohen is Assistant Professor at the Institute of Communication, Culture, Information, and Technology at the University of Toronto Mississauga (cross-appointed to the Faculty of Information). She researches freelance journalism and collective 
organizing and, with Greig de Peuter and Enda Brophy, cultural workers' collective responses to precarity (culturalworkersorganize.org). Her work has been published in South Atlantic Quarterly, Democratic Communiqué, The Canadian Journal of Communication, and Feminist Media Studies.

Greig de Peuter is Assistant Professor in the Department of Communication Studies at Wilfrid Laurier University in Waterloo, Canada. He is co-author of Games of Empire: Global Capitalism and Video Games (with Nick Dyer-Witheford).

Anibel Ferus-Comelo has a PhD in economic geography from the University of London and is currently involved in research and education in India. She is co-editor of Globalization, Knowledge and Labour: Education for Solidarity within Spaces of Resistance (with Mario Novelli).

Christian Fuchs is Professor of Social Media at the University of Westminster's Communication and Media Research Institute. His fields of work are critical theory, critical internet and social media research, digital labor, and critical information society studies.

Kelly Gates is Associate Professor of Communication and Science Studies at the University of California, San Diego. Her research, writing, and teaching examine the political and cultural dimensions of surveillance technologies and digital media. She is the author of Our Biometric Future: Facial Recognition Technology and the Culture of Surveillance.

Elizabeth Grossman is an independent journalist specializing in environmental and science issues. Her writing on these subjects has appeared in High Tech Trash and Chasing Molecules (both published by Island Press), in a report published by Dēmos, and in articles that have appeared in publications that include the Washington Post, Yale e360, Scientific American, National Geographic News, Salon, Mother Jones, Ensia, The Pump Handle, Environmental Health Perspectives, The Guardian, Civil Eats, Earth Island Journal, The Nation and Orion.

Leon Gurevitch is the Deputy Head of School, Royal Society Research Scholar, and Senior Lecturer in the School of Design at the Victoria University of Wellington, New Zealand. Leon's research ranges from digital image production and consumption cultures to new media advertising practices, eco-media, energy, and audiovisual culture.

David Hesmondhalgh is Professor of Media, Music, and Culture in the School of Media and Communication at the University of Leeds. He is the author of Culture, Economy and Politics: The Case of New Labour (with Kate Oakley, Melissa Nisbett, and David Lee); Why Music Matters; Creative Labour: Media Work in Three Cultural Industries (with Sarah Baker); and The Cultural Industries, now in its third edition.

Carey L. Higgins-Dobney is a doctoral student in Urban Studies at Portland State University. She has worked in local television news since 1997 and is currently a newscast director in Portland, Oregon. Her research interests include the political economy of the media, labor conditions in the media, and the role the news media play in the 


\section{NOTES ON CONTRIBUTORS}

shaping of communities and democracy. She has authored and published several articles on the media industry.

Yu Hong is Assistant Professor in the Annenberg School of Communication at the University of Southern California. She received her $\mathrm{PhD}$ in Communication from the University of Illinois at Urbana-Champaign. Her book Labor, Class Formation, and China's Informationized Policy of Economic Development explores China's evolving class relations in the ICT sector as China has become a global ICT manufacturing powerhouse.

Jocelyn Horner is a doctoral student in the interdisciplinary $\mathrm{PhD}$ program on City, Culture, and Community at Tulane University. Her research focuses on the relationship between youth development, civic and social engagement, and creative self-expression. She is also interested in the social dimensions of learning, gender and sexuality, action research, community development, and educational policy and practice.

John A. Lent taught at the college/university level from 1960 to 2011, including stints in the Philippines, Malaysia, Canada, China, and the United States. Prof. Lent pioneered the study of mass communication and popular culture in Asia (since 1964) and the Caribbean (since 1968), comic art and animation, and development communication. He has authored or edited seventy-eight books; published and edited the International Journal of Comic Art (which he founded), Asian Cinema (1994-2012), and Berita (1975-2001); and chaired Asian Popular Culture (PCA), the Asian Cinema Studies Society (1994-2012), the Comic Art Working Group (IAMCR), the Asian-Pacific Animation and Comics Association, the Asian Research Center for Animation and Comics Art, and the Malaysia/Singapore/Brunei Studies Group of Association for Asian Studies, all of which he founded.

Richard Maxwell is Professor of Media Studies at Queens College, City University of New York. His research has focused on international communication and media, political economy and media, surveillance and data protection, and the environmental impact of media. His recent publications include Media and the Ecological Crisis and Greening the Media.

Vicki Mayer is Professor of Communication at Tulane University. Her recent work includes Below the Line: Producers and Production Studies in the New Television Economy, Production Studies: Cultural Studies of Media Industries, and a website dedicated to the history of New Orleans' media and cultural production: http://www.medianola.org.

Toby Miller was Distinguished Professor of Media and Cultural Studies at the University of California-Riverside until the end of 2013 and is now Professor of Journalism, Media, and Cultural Studies at the University of Cardiff, the Sir Walter Murdoch Professor of Cultural Policy Studies at Murdoch University in Australia, and Profesor Invitado at the Universidad del Norte in Colombia. His latest two edited books are The Sage Handbook of Television Studies and The Routledge Companion to Global Popular Culture. http://www.tobymiller.org/.

Vincent Mosco is Professor Emeritus of Sociology at Queens University, where he held the Canada Research Chair in Communication and Society. He is the author of 
numerous books and articles on the media and information technology, including To the Cloud: Big Data in a Turbulent World, The Political Economy of Communication, and The Digital Sublime: Myth, Power, and Cyberspace.

Kaarle Nordenstreng is Professor Emeritus of Journalism and Mass Communication at the University of Tampere, Finland. He was a consultant to UNESCO in the 1970s and served as Vice President of the International Association for Media and Communication Research (1972-1988) and President of the International Organization of Journalists (1976-1990). He is currently working on a history of the international movement of journalists, including a new volume of Useful Recollections. http://www.uta.fi/cmt/en/ contact/staff/kaarlenordenstreng/index.html

Kate Oakley is Professor of Cultural Policy and Director of Research in the School of Media and Communication at the University of Leeds. Her research interests include the politics of cultural policy, work in the cultural industries, and regional development. Her latest book is The Routledge Companion to the Cultural Industries (with Justin O'Connor).

Rune Ottosen is a political scientist and journalist and Professor of Journalism at Oslo and Akershus University College of Applied Sciences. He has published widely on a range of topics, from Norwegian press history, to the role of journalists, to media coverage of war and conflicts. His recent work includes New Media $\mathcal{E}$ World Order? Professional and Legal Challenges for Conflict Reporting (with Stig A. Nohrstedt) and The Longest War. Media Coverage of the Norwegian Military Presence in Afghanistan (with Elisabeth Eide).

Pauline Overeem is the international coordinator of the GoodElectronics Network-a network of civil society organizations and individuals concerned about human rights and sustainability issues in the global electronics supply chain. The network is hosted by the Centre for Research on Multinational Corporations (SOMO) in Amsterdam. Her research analyzes corporations and supply chains, with a focus on the electronics and textiles and garments sectors in Asia. She is the author of Reset: Corporate Social Responsibility in the Global Electronics Supply Chain, published by the GoodElectronics Network and the Dutch MVO Platform. She is co-author of a series of reports for SOMO on labor rights violations in the textiles and garments industry in South India, including Captured by Cotton, Maid in India, and, most recently, Flawed Fabrics.

Ngai Pun is Professor in the Department of Applied Social Sciences at Hong Kong Polytechnic University. She is the author of Made in China: Women Factory Workers in a Global Workplace, for which she won the C. Wright Mills Award. The book has been translated into French, German, Italian, Polish, and Chinese. She has published numerous articles in Modern China, China Journal, China Quarterly, Global Labor Journal, Cultural Anthropology, Feminist Economics, Current Sociology, The Third World Quarterly, and Work, Employment and Society, among others. Recently, she co-authored and co-edited four books on construction workers, Foxconn workers, and social economy in Hong Kong and China.

Jack Linchuan Qiu is Associate Professor in the School of Journalism and Communication at the Chinese University of Hong Kong. He is the author of Working-Class 
Network Society and serves on the editorial boards of many international journals. Jack enjoys working with grassroots labor NGOs.

Chad Raphael is Professor of Communication at Santa Clara University. He chaired the boards of the Silicon Valley Toxics Coalition, the first advocacy group for environmental justice in the electronics industry, and the Jessie Smith Noyes Foundation, which funds similar work. Chad advises advocacy groups and governments on environmental communication campaigns and public engagement. His most recent book, with Christopher Karpowitz, is Deliberation, Democracy, and Civic Forums: Improving Equality and Publicity.

Pedro Antonio Reyes Linares has worked at CEREAL (Centro de Reflexión y Acción Laboral) since 1997, being one of its founding members. With CEREAL, he has served as a trainer, media coordinator, and educator with electronics workers and unions. $\mathrm{He}$ has studied philosophy at the doctoral level and has done graduate work in the social sciences and theology. He has published collaborations in different magazines about human rights and labor rights.

Luis Reygadas is Research Professor in the Department of Anthropology at the Universidad Autónoma Metropolitana Iztapalapa in Mexico City. Recent books include Indelible Inequalities in Latin America: Insights from History, Politics and Culture and La Apropiación: Destejiendo las Redes de la Desigualdad.

Ned Rossiter is Professor of Communication at the Institute for Culture and Society, University of Western Sydney, and teaches at the School of Humanities and Communication Arts. His forthcoming book is titled Software, Infrastructure, Labor: A Media Theory of Logistical Nightmares.

Dan Schiller is Professor Emeritus of Communication and of Library and Information Science at the University of Illinois Urbana-Champaign. His most recent book is Digital Depression: Information Technology and Economic Crisis.

Mark Selden is Research Fellow at the Asian/Pacific/American Studies Institute at New York University, Senior Research Associate in the East Asia Program at Cornell University, and editor of The Asia-Pacific Journal: Japan Focus. His work has ranged broadly across themes of war and revolution, inequality, development, regional and world social change, social movements, and historical memory. Books include China in Revolution: The Yenan Way Revisited; The Political Economy of Chinese Development; Chinese Village, Socialist State; Chinese Society: Change, Conflict and Resistance; and The Resurgence of East Asia: 500, 150 and 50 Year Perspectives.

Ted Smith is founder and former Executive Director of the Silicon Valley Toxics Coalition, a co-founder and chair of the steering committee of the Electronics TakeBack Coalition, and a co-founder and coordinator of the International Campaign for Responsible Technology, an international network committed to working for the development of sustainable, non-polluting technologies. He is a widely published author and is co-editor of Challenging the Chip: Labor Rights and Environmental Justice in the Global Electronics Industry. Ted was recognized by the Dalai Lama for his environmental leadership in 2001. He is a graduate of Wesleyan University and Stanford Law School. 
Gerald Sussman is Professor of Urban, Media, and International Studies at Portland State University and writes about communications in the service of corporate and state power. He is the author or editor of six books, including, most recently, The Propaganda Society: Promotional Culture and Politics in Global Context (2011); Branding Democracy: U.S. Regime Change in Post-Soviet Eastern Europe (2010); and Global Electioneering: Campaign Consulting, Communications, and Corporate Financing (2005).

Wei Wang is a doctoral student at the Annenberg School for Communication and Journalism at the University of Southern California. She received her bachelor's degree in sociology from Peking University and obtained her master's degree in sociology from Columbia University. She is interested in online activism, digital capitalism, and rural development in China.

Janet Wasko is the Knight Chair in Communication Research, Professor of Media Studies, and the Graduate Area Director in the School of Journalism and Communication at the University of Oregon. She is author, co-author, or editor of nineteen books, including Understanding Disney: The Manufacture of Fantasy; Dazzled by Disney: The Global Disney Audience Project; and The Handbook for Political Economy of Communications. She is currently serving as the President of the International Association for Media and Communication Research.

Simone Wolff is Associate Professor in the Department of Social Sciences and the Graduate School of Social Sciences at the State University of Londrina, Brazil. She received her $\mathrm{PhD}$ in the social sciences with an emphasis in the sociology of labor, acting on the following topics: production and corporate restructuring, work and information technology, digital work, capital-labor ratio, organization and labor relations, management, production processes and work, and micro-enterprises. Her postdoctoral work was conducted at the University of Hertfordshire-UK under the supervision of Dr. Ursula Huws.

Soenke Zehle is a media theorist and lecturer in media theory/netculture at the Academy of Fine Arts Saar, Germany, where he co-initiated and currently works as managing director of the academy's xm:lab-Experimental Media Lab. Drawing on his background in comparative literature, philosophy, and translation, he co-develops artsand-technology research projects and publishes regularly on algorithmic cultures. 


\section{4 \\ CHINESE LABOR PROTEST AND TRADE UNIONS \\ Jenny Chan, Ngai Pun, and Mark Selden}

Foxconn Technology Group, a Taiwanese-owned transnational corporation founded in Taipei in 1974, holds more than 50 percent of the market share in global electronics manufacturing. ${ }^{1}$ Its 1.4 million workers in China are comprised mostly of rural migrants in their late teens to twenties. This chapter considers their struggle for labor rights, the nature of union representation at the giant firm, and the joint responsibility of the enterprise and government for the protection of workers.

Yu Zhonghong (a pseudonym), a 21-year-old worker-protestor, sent an open letter to Foxconn CEO Terry Gou, which ended with three reminders (the letter is on file with the authors, our translation):

1. Please remember, from now on, to treat your subordinates as humans, and require that they treat their subordinates, and their subordinates, and their subordinates, as humans.

2. Please remember, from now on, those of you who are riding a rocket of fast promotions and earning wages as high as heaven compared to those on earth, to change your attitude that Taiwanese are superior.

3. Please remember, from now on, to reassess the responsibilities of the company union so that genuine trade unions can play an appropriate role.

Beginning late on September 23, 2012, Sunday night, and continuing through the morning of September 24, tens of thousands of workers rioted at the 80,000-worker Foxconn Taiyuan factory in Shanxi province, northern China, causing the shutdown of entire production lines for that day and disrupting the manufacturing of metal parts for iPhone $5 .{ }^{2}$ Several dozen workers were beaten by company security officers, and by 3 a.m., some 5,000 armed police were dispatched to the scene. Provincial governor Wang Jun rushed to the plant to restore law and order. In the aftermath of the riots, grievances over wages and benefits, promotions, and humiliating treatment of workers remained unaddressed. Communications between workers and management, particularly senior managers, were blocked.

In May 2013, an external audit report stated that at Foxconn factories across the Chinese mainland, "the percentage of worker representatives in the main union committees increased significantly." ${ }^{3}$ Echoing the report, Foxconn trumpeted that its trade union expanded from four representatives in 2007 to 23,000 representatives in $2013 .{ }^{4}$ 


\section{Copyright Taylor \& Francis - for author use only. \\ CHINESE LABOR PROTEST AND TRADE UNIONS}

But neither the union election methods nor the representatives' rights and responsibilities have been disclosed. What is the relationship between the creation of a large company union at Foxconn and the repeated labor struggles that have erupted at its plants over the last few years?

In the following, we draw on our 2010-2014 research to discuss workers' perception of the Foxconn Trade Union and the failure of the union to protect workers. Our interviews with Foxconn workers, trade union staff, and human resources managers, supplemented with published studies on recent Chinese trade union reforms, explain workers' fears, purposes, and rationales behind their protests. In conclusion, we assess the prospects for an ongoing labor campaign to increase workers' power at the point of production.

\section{Labor, the Chinese State, and Global Capital}

An analysis of the exploitations of Chinese labor reveals a strong link to global capital. With China's re-insertion into global capitalism from the 1970s to the present, many manufacturers have become contractors or subcontractors to branded merchandisers and retailers. At the center of world electronics manufacturing, Foxconn workers producing products for Apple, Microsoft, Google, Samsung, Dell, Sony, Amazon, and other global brands, face pressures compounded by fierce market competition and a disciplinary regime at work. Price squeeze by global buyers leads manufacturing firms to compromise workers' health and safety and to keep wages low. At high human costs, Chinese-state elites, at both the center and the localities, join hands with global capital to reinforce the prerogatives of market forces as universal, natural, inevitable, and irresistible.

Neoliberals believe that "human well-being can best be advanced by liberating individual entrepreneurial freedoms and skills within an institutional framework characterized by strong private property rights, free markets, and free trade." ${ }^{6}$ China well illustrates the stark reality that follows from this logic: increased income polarization and structural inequality across the class and urban-rural divide, exacerbated by state withdrawal from the employment and welfare protection of workers. ${ }^{7}$ Under intense market competition during the 1990s, many small and medium state firms went bankrupt, were privatized, or restructured, throwing an estimated 35 to 60 million urban workers out of work. ${ }^{8}$ In the three years from 1997 to 2000, the only officially recognized Chinese trade union organization, the All-China Federation of Trade Unions (ACFTU), whose strength had been centered in state-owned enterprises, lost at least 17 million members. ${ }^{9}$

The fragmentation of labor and the diversification of ownership at the hands of Chinese and international capital have profoundly challenged both workers and trade unions. With the influx of foreign direct investment and the relaxation of state restrictions on rural-to-urban migration since the 1980s, successive cohorts of internal migrant workers have simultaneously become the core of the new industrial working class and been exposed to market risks and uncertainty. ${ }^{10}$ By 2013, some 268 million rural migrants were drawn into industrialization and urbanization. ${ }^{11}$ Many of them are employed at booming private domestic and foreign firms in the electronics industry.

Responding to mounting worker actions in an era of rampant inequality, Chinese leaders have supported greater participation of workers in union organization in the hope that enterprise-level unions will help maintain social stability. ${ }^{12}$ The officials have 


\section{Copyright Taylor \& Francis - for author use only. \\ CHAN, PUN, AND SELDEN}

swiftly targeted foreign-invested companies to unionize. By December 2009, "unions had been set up in 92 percent of the Fortune 500 companies operating in China," including the then million-worker strong Foxconn, and this trend has continued since. ${ }^{13}$ As of December 2012, the Chinese trade union federation had a total membership of 258 million, ${ }^{14}$ surpassing the ITUC (International Trade Union Confederation) global membership of 176 million workers in 161 countries and territories excluding China. ${ }^{15}$ The attainment of this high level of unionization in large profitable enterprises is impressive. This stands in sharp contrast to the US, Europe, Australia, and many other countries, where in recent decades, private-sector labor unions have shrunk to a small percentage of the workforce, due to corporate restructuring, job export to China and elsewhere, and the replacement of core regular labor with part-time and temporary labor. ${ }^{16}$ But what are the consequences of unionization for Chinese workers? Our analysis of the Foxconn Trade Union-the largest union in the country-reveals how dependence on management severely undermines the capacity of unions to represent the workers, resulting in a distancing of workers from the union, one that is particularly evident in moments of crisis.

\section{The Foxconn Company Union: China's Largest Union}

From 1988 (when Foxconn set up its offshore factory in Shenzhen on the north border of Hong Kong in southeastern coastal China) through 2006, Foxconn, like many other wholly owned foreign-invested enterprises, evaded its legal responsibility to establish a trade union. On the last day of 2006, under pressure from the Shenzhen government and Shenzhen Federation of Trade Unions, the first step toward unionization was finally taken when local union officials signed up 118 Foxconn workers as members, out of the 240,000 workers at the Longhua factory. ${ }^{17}$ Taking immediate control of the newly formed union, beginning from 2007, Foxconn founder and CEO Terry Gou appointed his special personal assistant Chen Peng as chairwoman. She has since held the position. ${ }^{18}$ The Foxconn union organization mirrors the company hierarchy, from the assembly lines, departments, and business groups, to the corporate administrative level. In this, Foxconn's union committee structure is similar to many others: surveys of enterprise union leaders consistently reveal that a majority are concurrently board directors, personnel department heads, or senior managers who normally stand with management rather than with workers, according to Kong Xianghong, vice chair of the Guangdong Provincial Federation of Trade Unions (GDFTU). ${ }^{19}$

During our fieldwork, we learned about the Foxconn Trade Union's response to the tragedy of employee suicides. Foxconn shocked the world when the "12 leaps"-the attempted and completed suicides of young workers who leaped from high-rise factory dormitories in Shenzhen-took place during the first five months of 2010. ${ }^{20}$ Union chairwoman Chen not only failed to investigate the workplace factors responsible for worker depression but also made insensitive public comments that "suicide is foolish, irresponsible and meaningless and should be avoided." 21 What has the union done to prevent more employees from taking their lives or to alleviate their grievances? To address these questions, consider the activities promoted by the union.

At the Longhua facility, in 2010, all 249 union committee members were administrators appointed by management (interview, August 23, 2010). A team of female and male union staff reports for duty at the Employee Care Center during three work shifts a day, seven days a week. Each member of the Foxconn union staff wears a red 


\section{Copyright Taylor \& Francis - for author use only. \\ CHINESE LABOR PROTEST AND TRADE UNIONS}

badge with the ACFTU logo during office hours. Workers can easily identify and find them. In August 2010, the Foxconn union organized public speaking contests on the theme, "The company loves me, I love the company," to promote itself and the company. Foxconn also set up a 24-hour "care hotline," first at the Shenzhen plants and then at all 30 company factories across China. Workers can call 78585-the hotline's phonetic equivalent in Mandarin is "please help me, help me." The company union staff promises to "listen to your heart, solve your problems-anytime, anywhere." The company-run hotline and counseling service at the Employee Care Center is still in place.

Li Xiaoxiang, a 17-year-old worker, said:

After the suicide wave, we were soon required to take part in the "Cherish My Life" rally in August 2010. Since then, the union has organized day trips, picnics, hiking, fishing, singing contests, concerts, dance shows, basketball tournaments, and annual partner matching parties on Valentine's Day. These could help workers relax to some extent. However, we're exhausted from work. ${ }^{22}$

The most frequent union activities were the box-sealing competitions. Xiaoxiang explained that "box-sealing is what happens after products are stuffed into boxes; the box is sealed. This is one operation on the production line. The competition is to see who can seal the boxes fastest." The thinly disguised productivity-raising game is framed as a team-building activity. He added, "I'd say the union doesn't act according to workers' needs; rather the activities are based on company needs."

Foxconn's union mission statement tells workers, "When there's trouble, seek the trade union." However, most worker interviewees like Xiaoxiang see little point in doing so. When some workers lodged complaints, however, their caller identities were reported to management. Since learning of this breach of privacy, workers have hesitated to use the hotline or counseling services. They mock the company "care center," dubbing it the "supervision center," and the internal hotline the "management hotline." 23 If the hotline was of little use to workers seeking help, it did help Foxconn create an impression that it cares, while tightening the grip of management over workers. Most workers interviewed perceived the union as either "untrustworthy" or "useless" when it came to negotiations over wages and benefits, work injury compensation, employment contract terms, and labor dispute settlements.

In our interviews, Xie Mingli, a human resources manager, admitted that his thinking had been changing over the previous year, particularly after moderating an online forum for "Foxconn Friends" following the 2010 suicide wave. "We give advice to young workers in distress, the 16- and 17-year-olds. We emphasize that the workers have rights, fairness and dignity." He added:

The Foxconn trade union is a political ornament used to legitimate management in the eyes of corporate customers and government officials. How can we trust the union chairwoman as a mediator when she is a special assistant to the CEO? Workers' collective action and capacity building is fundamental to social progress, and should complement the ongoing legal reforms. ${ }^{24}$

The creation of a vast union bureaucracy at Foxconn merely masks the reality that workers and staff lack the right to a collective bargaining apparatus. 


\section{Copyright Taylor \& Francis - for author use only. \\ CHAN, PUN, AND SELDEN}

\section{Labor Protest}

In recent years, labor disputes have grown in number and intensity as Foxconn accelerated its move to lower-wage interior regions, whose major cities are rapidly being transformed into mega production bases for global brands, including notably Apple and Intel. In early 2012, soon after the Chinese New Year Festival, thousands of workers were transferred from Shenzhen to Wuhan, the provincial city of central China's Hubei. Workers could accept the transfer or lose their jobs. Not only were their wages cut, but the move resulted in a loss of welfare benefits. Su Hualing, 19, explained her anger: "My health insurance plan cannot be transferred from Shenzhen to Wuhan. Are my employer's contributions to the Shenzhen social security scheme over the past two years all gone? I am told that I can only claim my own premiums, but not those of the employer." ${ }^{25}$ This is despite the fact that she and many other transferees remain Foxconn employees.

The Shenzhen government department kept the 10 percent monthly contributions made by Foxconn based on Hualing's basic pay. The inability of rural migrant workers to carry their health insurance benefits and pensions to new localities when they change jobs, due to the lack of coordination between government administrative institutions, has been a chronic problem throughout China. ${ }^{26}$ Foxconn did not compensate its workers for their loss of entitlements. Instead, it stated that the Shenzhen government had not permitted the company to carry forward the insurance premiums for its transferred employees, thus pinning blame for the problem on the local government. Nor did the Foxconn company union act on workers' behalf in this situation. The subordination of the union to enterprise management is a major obstacle to the protection of workers' rights and interests in grievance resolution. ${ }^{27}$ As a result, Hualing and her co-workers had no choice but to withdraw their own individual payments from the insurance account from the Shenzhen Human Resources and Labor Security Bureau. They were unable, however, to recoup the payments that Foxconn made in their names. "I'm very upset," Hualing said.

The loss was not limited to health insurance and pensions. The basic monthly pay at the new plant Foxconn Wuhan (1,350 Yuan) was 13 percent lower than in Shenzhen (1,550 Yuan). Worse yet, during February and March 2012, managers cancelled workers' weekend overtime pay, replacing it with compensatory time off. Under this policy, designed to cut overtime payments, many workers only made basic wages, despite putting in "more than 15 hours of overtime work on the weekends." 28 The reason is that workers were not paid double wages for overtime work on Saturdays and Sundays; instead, the company offered "free time" in lieu of the overtime wages in the weeks following peak intensity periods, taking a "flexible approach" to fulfill the legal requirements over rest days, working hours, and pay. ${ }^{29}$ On the morning of April 25, 2012, when workers received their wage statements for the month, anger boiled over at this injustice.

Nearly 200 workers in a mold-stamping workshop took the lead in walking off the factory floor. On the roof of the three-story building, they chanted, "Wo yao jiaxin!" (I want a raise!) and "Li Wenzhong, gundan!" (Down with Li Wenzhong [the business group leader]!). After a standoff of more than ten hours, city government officials and local trade union cadres were forced to step into the worker-management negotiations. Time and again, settlement of high-profile worker protests through government mediation is undertaken to restore "industrial harmony." Indeed, officials have skillfully 


\section{Copyright Taylor \& Francis - for author use only. \\ CHINESE LABOR PROTEST AND TRADE UNIONS}

developed "protest absorption" techniques to settle labor disputes at the scene with the goal to maintain sociopolitical stability. ${ }^{30}$ While it is unclear how long this government interventionist strategy will remain viable, particularly when workers' basic rights and interests are routinely violated in the radical transformation of the economy; in our example, the ticking bomb of a prolonged walkout or mass suicides at Foxconn was removed. The protesting workers did not succeed in having the business group chief removed from his position, but they won hard-earned weekend overtime wages.

It is noteworthy that the aggrieved workers did not face obstruction from their line and team leaders during the protest. Wang Shuping, a 23-year-old line leader, explained, "We were concerned about the big problem as our own interests had been similarly hurt by the forced transfer and subsequent wage and benefit cuts." ${ }^{31}$ Indeed, this was a rare instance in which the interests of frontline workers and line leaders were aligned. Several line leaders encouraged the new workers to join the industrial action without fear of retaliation from them. Following the protests, Foxconn senior managers have demanded that frontline leaders not support disruptive actions. The pledge, reprinted online at the Boxun Net, states:

As a manager of the company, regardless of the reason, I will not insinuate, instigate, or incite employees to use improper means to express their demands. Under no circumstance will I participate in an illegal assembly, march, demonstration, organization, or activity. Should I discover employees' participation in an illegal assembly, march, demonstration, organization or activity, I will persuade them to stop and report it immediately. ${ }^{32}$

The Foxconn company union has repeatedly failed to protect workers' rights and interests. Rather, workers are repeatedly subjected to harsh discipline and strict order maintained by management and the union. Behind the company's hype of "mutual care and love," the daily life of a Foxconn worker is the pressure to fulfill high output quotas and tight delivery deadlines. A 24-year-old worker summarized: "At Foxconn, the deeper problem behind the pressure of high-stress, low-income jobs is the restriction on workers' right to join together, find their voice and defend their collective interests." ${ }^{33}$

\section{Trans-border Labor Activism}

The integration of Asian manufacturers in global production networks and tight delivery schedules for consumer electronics products, however, has also enhanced workers' bargaining power at the workplace level. In her longitudinal survey of world labor movements since 1870, Beverly Silver documents the rise of new working class forces in sites of capital investment at specific historical conjunctures. She defines "workplace bargaining power" as the power that "accrues to workers who are enmeshed in tightly integrated production processes, where a localized work stoppage in a key node can cause disruptions on a much wider scale than the stoppage itself." ${ }^{34}$ In contemporary social struggles, Frances Fox Piven succinctly discusses the nature of "interdependent power" and highlights the fact that employers are dependent on workers' consent to labor, perhaps more dependent than ever before. She writes:

Distinctive features of contemporary capitalist economies make them exceptionally vulnerable to the withdrawal of cooperation; in other words, to the 


\section{Copyright Taylor \& Francis - for author use only. \\ CHAN, PUN, AND SELDEN}

strike power in its many forms. These features include extended chains of production, reliance on the Internet to mesh elaborate schedules of transportation and production, and just-in-time production doing away with the inventories that once shielded corporations from the impact of the production strike. ${ }^{35}$

With workers' growing awareness of the opportunities presented by the fact that giant corporations like Foxconn face pressures to meet quotas for new models and holiday season purchases, they have come together at the dormitory, workshop, or factory level to voice demands or to stage protests. Access to internet and social networking technology also enables workers to disseminate open letters and to tweet urgent appeals for support. ${ }^{36}$ Some have joined with labor campaign groups, such as the Hong Kong-based Students and Scholars Against Corporate Misbehavior (SACOM), to pressure IT companies to respond to their demands. This alliance of workers and non-governmental labor organizations in organizing, in our view, is a response to limitations of workplace-based dispute resolution institutions and constraints in union organizations.

In the wake of Foxconn suicides and protests, Apple and other transnational corporations responded to chronic labor problems in supplier factories by reiterating their commitment to good governance in an attempt to distance themselves from responsibility for the abuses of their suppliers and burnish their reputation internationally. ${ }^{37}$ Apple-Foxconn's largest corporate client—pledges to protect workers' dignity, wages and benefits, working hours, health and safety, and their rights to "seek representation" and "bargain collectively" in its global supply chain. ${ }^{38}$ This is in part a response to the growing anti-sweatshop movement in the electronics industry from within the US, Europe, and more recently Greater China. Many image-conscious technology companies, probably none more than Apple in our digital age, have professed ideals of corporate citizenship, environmental, and labor and social responsibility in their supplier codes of conduct. ${ }^{39}$ Yet, they refuse to accept responsibility for abuses that stem directly, in many instances, from their demands for high volume and rapid delivery of new products. Violations of factory workers' fundamental rights in export-oriented industries remain intractable.

For their part, Foxconn workers have come to realize the huge discrepancy between company labor codes and the reality of compulsory overtime work and managerial abuses on the factory floor. They present the plight of their working lives to media agencies and credible labor support groups, hoping to "create a sense of moral accountability" to urge the target corporations to live up to their professed global corporate-citizenship ideals. ${ }^{40}$ They amplify their voices in letters, poems, songs, slogans, weblogs, and documentaries, sometimes with the assistance of concerned Chinese and international students, researchers, and labor activists.

In response to pressing questions concerning trade union organization and worker representation, in February 2012, Foxconn senior executive Louis Woo told ABC News:

We do have labor unions at Foxconn, but it's not a freely elected labor union yet. I expect to see that in the next year or two they will become more like a collective bargaining union, and they will be freely elected. In fact I see that some legislation in more progressive provinces would require labor unions to be sitting on the boards of companies. So I do see hope of labor unions becoming more powerful-but it's not here yet. ${ }^{41}$ 


\section{Copyright Taylor \& Francis - for author use only. \\ CHINESE LABOR PROTEST AND TRADE UNIONS}

Free election of union leadership is crucial to win legitimacy and popular support. And yet union-building, with the active involvement of informed workers, is a long and painstaking process. Chinese workers are accumulating organizing skills and demanding with greater persistence their rights to decent wages, safe and healthy working conditions, and responsive union representation. Some have acquired experience in direct union elections at the enterprise level, such as those in Reebok supplier factories in the early 2000s and Walmart retail stores in 2006. ${ }^{42}$ In fact, free nomination of candidates and direct union elections are not new. In 1988, the top-echelon union federation leaders, based on direct elections in Shenzhen, drafted a document entitled "Basic Thoughts on Trade Union Reform," which envisioned that "trade union leaders at all levels should be democratically elected." The initiative was shelved following the crackdown on the 1989 Tiananmen Movement. ${ }^{43}$ From the mid-1990s, against the background of radical restructuring resulting in the loss of union members in the state sector, some government leaders have supported expansion of unions and greater worker participation in their activities.

In an attempt to build a global trade union movement, progressive union leaders and activist-intellectuals from the West were eager to build a link with the Chinese union federations at all levels, contemplating that the ACFTU, holding the largest membership union, could be a major partner in this ambitious project. It has been observed that "a new generation of union leaders in China" is more open than their predecessors to ideas of "co-determination and works council systems in Europe" and union organizing methods from the US and other countries. ${ }^{44}$ In principle, global engagement with Chinese state institutions, including the ACFTU, should contribute to a more powerful world labor movement. At the same time, the harsh fact is that "unionized" workers at Foxconn and many other workplaces do not enjoy fundamental social and legal protections such as the right to strike, to engage in collective bargaining, or to form autonomous unions. Domination and control of enterprise unions by management remains a basic fact.

In light of the state union monopolistic structure, Tim Pringle discusses the future of Chinese union reforms, which "would require not just more accountable enterprise-level union chairpersons and committees but a more supportive, interactive and, at times, directive relationships between the higher trade unions and their enterprise-level subordinates. ${ }^{45}$ In 2010, in the midst of worker suicides at Foxconn factories and protracted strikes in Pearl River Delta industrial cities, Wang Tongxin, vice chair of the Shenzhen Federation of Trade Unions, called for "power to the workers" and supported the municipal government plan to facilitate direct union elections at 163 enterprises (each with more than 1,000 workers) whose union committees were up for reelection during the year and shortly after. ${ }^{46}$ Clearly, Foxconn has begun to feel mounting pressures directed toward building a worker-centered union.

Faced with the reality of trade unions that lack independence from either the state or capital, many workers under duress have turned to self-organization strategies, ignoring the company unions. Yu Zhonghong, one of the protesting workers (who we met in the opening of this chapter), declares in his letter to CEO Terry Gou (our translation):

You should understand that working in your factories:

Workers live at the lowest level,

Tolerating the most intense work, 


\section{Copyright Taylor \& Francis - for author use only. \\ CHAN, PUN, AND SELDEN}

Earning the lowest pay,

Accepting the strictest regulation,

And enduring discrimination everywhere.

Even though you are my boss, and I am a worker:

I have the right to speak to you on an equal footing.

The sense in which "right" is used is not narrowly confined to the realm of legal rights. Chinese workers in global production are demanding to bargain with their employers "on an equal footing."

In December 2013, Foxconn reiterated that "we have worked hard to enhance employee representation in the [union] leadership" and to raise employee awareness of the union's role in "promoting worker rights." ${ }^{47}$ If fair union elections and collective bargaining were guaranteed, beginning with Foxconn's mega factories in Shenzhen, this would be a landmark event for workers across China.

\section{Conclusion}

In class struggles, workers (and their supporters) are the agency of historical development, and their efforts will continue to bring about labor reforms and institutional changes. The oppressive conditions that confront Chinese workers in the market economy have led to a crescendo of protests since the early 1990s, with specific demands for access to economic and sociopolitical rights. With Foxconn and other large companies building subsidiaries and relocating workers from coastal to interior regions, worker protests are spreading throughout China.

How to establish a mechanism for resolving disputes through collective bargaining at the enterprise level under conditions of enterprise, state, and union policies in contemporary China? In October 2013, the Guangdong Provincial People's Congress released "Regulations on Enterprise Collective Consultations and Collective Contracts (Revised Draft)" for public discussion, with the goal of setting up an effective negotiation system so as to harmonize labor relations on principles of equality. The regulations specify that employees can initiate a "collective consultation" process, and management must present a point-by-point written reply within 20 days of receiving the notice (Article 25)..$^{48}$ In the face of strong opposition from major business associations, the provincial government weakened the critical provisions, and on September 25, 2014, passed "Regulations on Enterprise Collective Contracts in Guangdong," effective January 1, 2015. Article 18 stipulates that over 50 percent of the workforce should unanimously agree with the call for collective consultations; otherwise, the related procedures shall not be put in place. Article 24 does not recognize workers' fundamental rights to withdraw their labor as a means to bargain collectively with their boss, such as walking out, blocking the traffic, or disrupting the supplies to production. ${ }^{49}$ The regulations, in fact, in fundamental ways limit rather than empower workers' bargaining rights.

Deepening conflicts on the factory floor are fueling labor insurgency in China, and this, in turn, is shaping world labor politics. A young generation of workers, whose parents were the pioneers of internal migrant labor in the initial period of market reform, is now filling China's workplaces. As the backbone of the nation's industrial development, these younger, better-educated workers have considerably higher expectations than the first wave of rural-to-urban migrants. Aspiring to develop technical skills, earn living wages, enjoy comprehensive welfare, and organize trade unions, that is, to hold 


\section{Copyright Taylor \& Francis - for author use only. \\ CHINESE LABOR PROTEST AND TRADE UNIONS}

the full range of labor and human rights in the towns and cities they inhabit, they face immense obstacles in the prevailing order at Foxconn and other corporations. To realize their dreams, they will have to carry forward their fight for justice and equality.

\section{Notes}

1 Thomas Dinges, "Foxconn Rides Partnership with Apple to Take 50 Percent of EMS [Electronics Manufacturing Services] Market in 2011," iSuppli, July 27, 2010, accessed October 18, 2014. http:// www.isuppli.com/Manufacturing-and-Pricing/News/Pages/Foxconn-Rides-Partnership-with-Apple-toTake-50-Percent-of-EMS-Market-in-2011.aspx.

2 Yan Shuang, "Foxconn Shuts Plant after Violence," Global Times, September 25, 2012, accessed October 18, 2014. http://www.globaltimes.cn/content/735139.shtml.

3 Fair Labor Association, "Second Foxconn Verification Status Report," 2013, 4, accessed October 18, 2014. http://www.fairlabor.org/sites/default/files/documents/reports/second_foxconn_verification_status_ report_0.pdf\# overlay-context=.

4 Foxconn Technology Group, "Corporate Social and Environmental Responsibility Annual Report 2012," 2013, 14, accessed October 18, 2014. http://ser.foxconn.com/ViewAnuReport.do?action=showAnnual.

5 Steven C. McKay, Satanic Mills or Silicon Islands? The Politics of High-Tech Production in the Philippines (Ithaca, NY: Cornell University Press, 2006); Ted Smith, David A. Sonnenfeld, and David Naguib Pellow, eds., Challenging the Chip: Labor Rights and Environmental Justice in the Global Electronics Industry (Philadelphia: Temple University Press, 2006); Boy Lüthje et al., From Silicon Valley to Shenzhen: Global Production and Work in the IT Industry (Lanham, MD: Rowman and Littlefield, 2013); Asia Monitor Resource Center, Labour Rights in High Tech Electronics: Case Studies of Workers' Struggles in Samsung Electronics and Its Asian Suppliers (Hong Kong: Asia Monitor Resource Center, 2013); Jenny Chan, Pun Ngai, and Mark Selden, "The Politics of Global Production: Apple, Foxconn, and China's New Working Class," New Technology, Work and Employment 28(2) (2013): 100-15, doi: 10.1111/ntwe.12008; The Asia-Pacific Journal, Vol. 11, Issue 32, No. 2, August 12, 2013, accessed October 18, 2014. http://www. japanfocus.org/-Jenny-Chan/3981.

6 David Harvey, A Brief History of Neoliberalism (Oxford: Oxford University Press, 2005), 2.

7 Mark Selden and Elizabeth J. Perry, "Introduction: Reform, Conflict and Resistance in Contemporary China," in Chinese Society: Change, Conflict and Resistance, ed. Elizabeth J. Perry and Mark Selden, 3rd Edition (London: Routledge, 2010), 1-30; Marc Blecher, "Globalization, Structural Reform, and Labour Politics in China," Global Labour Journal 1(1) (2010): 92-111, accessed October 18, 2014, http://digitalcommons.mcmaster.ca/cgi/viewcontent.cgi?article=1025\&context=globallabour; Yin-wah Chu and Alvin Y. So, "State Neoliberalism: The Chinese Road to Capitalism," in Chinese Capitalisms: Historical Emergence and Political Implications, ed. Yin-wah Chu (Basingstoke: Palgrave Macmillan, 2010), 46-72; Joel Andreas, "Industrial Restructuring and Class Transformation in China," in China's Peasants and Workers: Changing Class Identities, ed. Beatriz Carrillo and David S. G. Goodman (Cheltenham, UK: Edward Elgar, 2012), 102-23.

8 Dorothy J. Solinger, States' Gains, Labor's Losses: China, France, and Mexico Choose Global Liaisons, 1980-2000 (Ithaca, NY: Cornell University Press, 2009); William Hurst, The Chinese Worker after Socialism (Cambridge: Cambridge University Press, 2009); Albert Park and Fang Cai, "The Informalization of the Chinese Labor Market," in From Iron Rice Bowl to Informalization: Markets, Workers, and the State in a Changing China, ed. Sarosh Kuruvilla, Ching Kwan Lee, and Mary E. Gallagher (Ithaca, NY: Cornell University Press, 2011), 17-35.

9 Rudolf Traub-Merz, "All China Federation of Trade Unions: Structure, Functions and the Challenge of Collective Bargaining," in Industrial Democracy in China: With Additional Studies on Germany, South-Korea and Vietnam, ed. Rudolf Traub-Merz and Kinglun Ngok (Beijing: China Social Sciences Press, 2012), 11-60.

10 Ching Kwan Lee, Gender and the South China Miracle: Two Worlds of Factory Women (Berkeley: University of California Press, 1998); Ching Kwan Lee, Against the Law: Labor Protests in China's Rustbelt and Sunbelt (Berkeley: University of California Press, 2007); Lisa Rofel, Other Modernities: Gendered Yearnings in China after Socialism (Berkeley: University of California Press, 1999); Mary Elizabeth Gallagher, Contagious Capitalism: Globalization and the Politics of Labor in China (Princeton, NJ: Princeton University Press, 2005); Pun Ngai, Made in China: Women Factory Workers in a Global Workplace (Durham, NC: Duke University Press, 2005); Jaesok Kim, Chinese Labor in a Korean Factory: Class, Ethnicity, 


\section{Copyright Taylor \& Francis - for author use only. \\ CHAN, PUN, AND SELDEN}

and Productivity on the Shop Floor in Globalizing China (Palo Alto, CA: Stanford University Press, 2013); Jenny Chan and Mark Selden, "China's Rural Migrant Workers, the State, and Labor Politics," Critical Asian Studies 46(4) (2014): 599-620, doi: 10.1080/14672715.2014.960709.

11 National Bureau of Statistics of the People's Republic of China, "Statistical Communiqué of the People's Republic of China on the 2013 National Economic and Social Development," February 24, 2014, accessed October 18, 2014. http://www.stats.gov.cn/english/PressRelease/201402/t20140224_515103.html.

12 Florian Butollo and Tobias ten Brink, "Challenging the Atomization of Discontent: Patterns of MigrantWorker Protest in China during the Series of Strikes in 2010," Critical Asian Studies 44(3) (2012): 419-40, doi: 10.1080/14672715.2012.711978; Chris King-Chi Chan and Elaine Sio-Ieng Hui, "The Development of Collective Bargaining in China: From 'Collective Bargaining by Riot' to 'Party State-led Wage Bargaining,” The China Quarterly 217 (2014): 221-42, doi: http://dx.doi.org/10.1017/ S0305741013001409; Eli Friedman, Insurgency Trap: Labor Politics in Postsocialist China (Ithaca, NY: Cornell University Press, 2014); Lu Zhang, Inside China's Automobile Factories: The Politics of Labor and Worker Resistance (New York: Cambridge University Press, 2014).

13 Mingwei Liu, “'Where There Are Workers, There Should Be Trade Unions': Union Organizing in the Era of Growing Informal Employment," in From Iron Rice Bowl to Informalization: Markets, Workers, and the State in a Changing China, ed. Sarosh Kuruvilla, Ching Kwan Lee, and Mary E. Gallagher (Ithaca, NY: Cornell University Press, 2011), 157.

14 China Labour Statistical Yearbook 2012 (Beijing: China Statistics Press, 2013), 405-6.

15 International Trade Union Confederation, "List of Affiliated Organizations," 2014, accessed October 18, 2014. http://www.ituc-csi.org/IMG/pdf/no_07_-_list_affiliates_03co_may_2014-2.pdf.

16 Edward Webster, Rob Lambert, and Andries Bezuidenhout, Grounding Globalization: Labour in the Age of Insecurity (Malden, MA: Blackwell Publishing, 2008); Jennifer Jihye Chun, Organizing at the Margins: The Symbolic Politics of Labor in South Korea and the United States (Ithaca, NY: Cornell University Press, 2009); Stephanie Luce and Edna Bonacich, "China and the U.S. Labor Movement," in China and the Transformation of Global Capitalism, ed. Ho-fung Hung (Baltimore, MD: Johns Hopkins University Press, 2009), 153-73; Rebecca Gumbrell-McCormick and Richard Hyman, "European Trade Unions: In Search of a Narrative," Labor History 54(4) (2013): 477-83, doi: 10.1080/0023656X.2013.843859.

17 IHLO (International Trade Union Confederation/Global Union Federation Hong Kong Liaison Office), "ACFTU (All-China Federation of Trade Unions) Established a Union at Foxconn on the Very Last Day of 2006,” January 2, 2007, accessed October18, 2014. http://www.ihlo.org/LRC/ACFTU/030107. html.

18 Interview, August 12, 2014.

19 Kong Xianghong, "Capacity-Building and Reform of Chinese Trade Unions: Using Legal and Democratic Means to Resolve the Conflict of Roles of Trade Union Chairs," in Industrial Democracy in China: With Additional Studies on Germany, South-Korea and Vietnam, ed. Rudolf Traub-Merz and Kinglun Ngok (Beijing: China Social Sciences Press, 2012), 80-82.

20 Jenny Chan and Pun Ngai, "Suicide as Protest for the New Generation of Chinese Migrant Workers: Foxconn, Global Capital, and the State," The Asia-Pacific Journal 37(2), September 13, 2010, accessed October 18, 2014, http://japanfocus.org/-Jenny-Chan/3408; Pun Ngai and Jenny Chan, "Global Capital, the State, and Chinese Workers: The Foxconn Experience," Modern China 38(4) (2012): 383-410, doi:10.1177/0097700412447164; Pun Ngai and Jenny Chan, "The Spatial Politics of Labor in China: Life, Labor, and a New Generation of Migrant Workers," The South Atlantic Quarterly 112(1) (2013): 179-90, doi: 10.1215/00382876-1891332; Jenny Chan, “A Suicide Survivor: The Life of a Chinese Worker," New Technology, Worker and Employment 28(2) (2013): 84-99, doi: 10.1111/ntwe.12007; Pun Ngai et al., "Worker-Intellectual Unity: Trans-Border Sociological Intervention in Foxconn," Current Sociology 62(2) (2014): 209-22. doi: 10.1177/0011392113514892; The Asia-Pacific Journal, Vol. 12, Issue 11, No. 3, March 17, 2014, accessed October 18, 2014, http://www.japanfocus.org/-Pun-Ngai/4093.

21 China Daily, "Foxconn Rallies to End Suicides by Workers," August 19, 2010, print.

22 Interview, October 15, 2010.

23 Interview, January 2, 2012.

24 Interview, October 28, 2011.

25 Interview, June 16, 2012.

26 Mark W. Frazier, "Social Policy and Public Opinion in an Age of Insecurity," in From Iron Rice Bowl to Informalization: Markets, Workers, and the State in a Changing China, ed. Sarosh Kuruvilla, Ching Kwan Lee, and Mary E. Gallagher (Ithaca, NY: Cornell University Press, 2011), 61-79. 


\section{Copyright Taylor \& Francis - for author use only. \\ CHINESE LABOR PROTEST AND TRADE UNIONS}

27 Feng Chen, "Union Power in China: Source, Operation, and Constraints," Modern China 35(6) (2009): 662-89, doi: 10.1177/0097700409344300.

28 Interview, April 2, 2012.

29 Interview with a human resources manager, April 5, 2012.

30 Yang Su and Xin He, "Street as Courtroom: State Accommodation of Labor Protest in South China," Law and Society Review 44(1) (2010): 157-84, doi: http://dx.doi.org/10.2139/ssrn.1447131; Feng Chen, "Trade Unions and the Quadripartite Interactions in Strike Settlement in China," The China Quarterly 201 (March) (2010): 104-24, doi: http://dx.doi.org/10.1017/S0305741009991093; Xi Chen, Social Protest and Contentious Authoritarianism in China (New York: Cambridge University Press, 2012); Ching Kwan Lee and Yonghong Zhang, "The Power of Instability: Unraveling the Microfoundations of Bargained Authoritarianism in China," American Journal of Sociology 118(6) (2013): 1475-508, doi: 10.1086/670802; Ching Kwan Lee, "State and Social Protest," Daedalus: The Journal of the American Academy of Arts and Sciences 143(2) (2014): 124-34, doi:10.1162/ DAED_a_00277; Mary E. Gallagher, "China's Workers Movement and the End of the Rapid-Growth Era," Daedalus: The Journal of the American Academy of Arts and Sciences 143(2) (2014): 81-95, doi:10.1162/DAED_a_00274.

31 Interview, May 10, 2012.

32 Boxun Net, "Wuhan Yuanqu Guanli Renyuan Guanli Zeren Chengnuo Shu" [Agreement to Wuhan Factory Management Responsibilities by Staff], May 16, 2012, accessed October 18, 2014. http://boxun.com/ news/gb/china/2012/05/201205162012.shtml.

33 Interview, December 20, 2012.

34 Beverly J. Silver, Forces of Labor: Workers' Movements and Globalization since 1870 (Cambridge: Cambridge University Press, 2003), 13; Erik Olin Wright, "Working-Class Power, Capitalist-Class Interests, and Class Compromise," American Journal of Sociology 105(4) (2000): 957-1002, accessed October 18, 2014. http://www.jstor.org/stable/3003886.

35 Frances Fox Piven, "Interdependent Power: Strategizing for the Occupy Movement," Current Sociology 62(2) (2014): 226, doi:10.1177/0011392113515138.

36 Jack Linchuan Qiu, Working-Class Network Society: Communication Technology and the Information Have-Less in China (Cambridge: MIT Press, 2009); Christian Fuchs, Digital Labour and Karl Marx (New York: Routledge, 2014).

37 Ralph A. Litzinger, "The Labor Question in China: Apple and Beyond," The South Atlantic Quarterly 112(1) (2013): 172-78, doi: 10.1215/00382876-1891314.

38 Apple, "Apple Supplier Code of Conduct," 2012, 3, accessed October 18, 2014. http://images.apple. com/supplierresponsibility/pdf/Apple_Supplier_Code_of_Conduct.pdf.

39 Apple, "Supplier Responsibility Standards," 2014, accessed October 18, 2014. http://www.apple.com/ supplier-responsibility/pdf/Apple_Supplier_Responsibility_Standards.pdf.

40 Gay W. Seidman, Beyond the Boycott: Labor Rights, Human Rights, and Transnational Activism (New York: Russell Sage Foundation, 2007), 32.

41 Bill Weir, "iFactory: Inside Apple," ABC News, February 19, 2012, accessed October 18, 2014. http:// news.yahoo.com/trip-ifactory-nightline-gets-unprecedented-glimpse-inside-apples-001926196-abcnews.html.

42 Anita Chan, "Challenges and Possibilities for Democratic Grassroots Union Elections in China: A Case Study of Two Factory-Level Elections and Their Aftermath," Labour Studies Journal 34(3) (2009): 293-317, doi:10.1177/0160449X08318425; Anita Chan, ed., Walmart in China (Ithaca, NY: Cornell University Press, 2011).

43 Jude A. Howell, "All-China Federation of Trade Unions Beyond Reform? The Slow March of Direct Elections," The China Quarterly 196 (December 2008): 845-63, doi: http://dx.doi.org/10.1017/S03057 4100800115X.

44 Kent Wong, "The AFL-CIO and China," U.S./China Media Brief, UCLA Asian American Studies Center, 2008, accessed October 18, 2014. http://www.uschinamediabrief.com/ee_aflciochina.shtml.

45 Tim Pringle, Trade Unions in China: The Challenge of Labour Unrest (Abingdon, UK: Routledge, 2011), 162.

46 Wang Tongxin, "Ba Quanli Jiaogei Gongren" [Power to the Workers], Chinese Workers, No. 5, 2013, accessed October 18, 2014. http://www.chineseworkers.com.cn/_d276227433.htm.

47 The seven-page company statement is on file with the authors.

48 The Standing Committee of Guangdong Provincial People’s Congress, "Guangdongsheng Qiye Jiti Xieshang he Jiti Hetong Tiaoli (Xiuding Caoan)" [Regulations on Enterprise Collective Consultations and 


\section{Copyright Taylor \& Francis - for author use only. \\ CHAN, PUN, AND SELDEN}

Collective Contracts (Revised Draft)], 2013, accessed October 18, 2014. www.rd.gd.cn/rdgzxgnr/flca zjyj/201310/t20131011_136865.html.

49 The Standing Committee of Guangdong Provincial People's Congress, "Guangdongsheng Qiye Jiti Hetong Tiaoli” [Regulations on Enterprise Collective Contracts], 2014, accessed October 18, 2014. http://www. gdrd.cn/gdrdfb/ggtz/201409/t20140928_142698.html. 